\title{
KONVERGENSI ISLAM DAN SAINS DALAM PERSPEKTIF FILSAFAT
}

\author{
Fatkhul Muin \\ Fakultas Hukum Universitas Sultan Ageng Tirtayasa \\ Jl. Raya Jakarta KM. 4 Pakupatan, Serang, Banten, 42118 \\ e-mail: fatkhulmoen@gmail.com
}

\begin{abstract}
Abstrak: Tulisan ini mencoba mengungkap hubungan antara Islam dan sains dalam perspektif filsafat. Dengan menggunakan pendekatan doktrinal kajian kepustakaan, tulisan ini membahas teori-teori yang digunakan untuk menentukan hakikat kebenaran dalam filsafat, yaitu teori realisme dan teori idealisme. Menurut penulis, perdebatan terhadap kedua teori tersebut tidak berakhir pada apa yang menjadi dasar penentuan kebenaran pengetahuan, tetapi juga pada perdebatan kepada asal pengetahuan itu sendiri. Hal tersebut melahirkan teori empirisme dan rasionalisme. Dalam hubungan antara agama dan ilmu pengetahuan, paling tidak terdapat empat kubu, yakni kubu konflik yang menganggap sains dan agama bertentangan; kubu kontras yang memandang bahwa antara agama dan sains berdiri sendiri; kubukontak atau dialog yang mencoba menjembatani antara kedua bidang ini; dan kubu konfirmasi yang berupaya bahwa sains harus diarahkan untuk kepentingan kemanusiaan. Dalam kajian ini, penulis menemukan bahwa konvergensi ilmu pengetahuan dan agama menjadi satu kesatuan yang terintegrasi.
\end{abstract}

\begin{abstract}
The Convergence of Islam and Science in the Perspective of Philosophy.This essay attempts to reveal the relationship between Islam and science in the perspective of philosophy. By utilizing doctrinal literature studies approach, this writing discusses theories that determine the essence of truth in the realm of philosophy, namely realism and idealism theories. According to the author, the debate on such theories would not terminate in what became the basis for determining the truth of knowledge, but also to the issue of the origin of the knowledge itself, which gave birth to the theory of empiricism and rationalism. With regard to the relationship between religion and knowledge, there are at least four mainstreams which include first, conflict that regards religion and science in contradiction; second, contrast that considers both as independent; third, contact or dialoguethat tries to bridge the two; and forth, confirmation which makes an effort to make both for human interest . In this study, the writer found that the convergence of knowledge and religion has turned into one integrated whole.
\end{abstract}

Kata Kunci: ilmu, agama, filsafat, sains, integrasi ilmu 


\section{Pendahuluan}

Filsafat sebagai titik dari pergulatan untuk mencari kebenaran, tentu tidak terlepas dari proses yang harus dijalankan oleh setiap manusia dalam mencari kebenaran tersebut. Filsafat dapat dijabarkan dalam perkataan philoshopia, dimana philos berarti cinta sedangkan sophos berarti kebijaksanaan atau pengetahuan yang mendalam. ${ }^{1}$ Jabaran tersebut dipahami sebagai proses bahwa manusia memiliki cinta terhadap kebijaksanaan atau sebuah pengetahuan yang mendalam. Nilai-nilai yang dikonstruksikan dalam filsafat adalah nilai-nilai akan kecintaan terhadap segala sesuatu secara mendalam dengan berlandaskan kepada nilai-nilai yang bersifat luhur.

Istilah "Cinta akan..." dipakai dengan cara yang berbeda-beda, baik sehubungan dengan perbuatan "mencinta", maupun dengan objeknya. Menurut perumusan Maurice Nedoncelle, seorang filusuf Prancis, cinta menuju promotion du toi (Mempromosikan "aku"). ${ }^{2}$ Artinya bahwa cinta akan, merupakan bagian yang penting dalam kehidupan manusia untuk mendapatkan dan mendalami sesuatu.

Cinta terhadap kebijaksanaan memberikan arti bahwa kebijaksanaan mengandung dua arti. Pertama, mempunyai insight, pengertian yang mendalam yang meliputi seluruh kehidupan manusia dalam segala aspeknya dan seluruh dunia dengan segala lapangannya serta hubungan antara kesemuanya itu. Kedua, sikap hidup yang benar, yang baik dan tepat. ${ }^{3}$ Makna bijaksana tersebut memberikan lapangan manusia untuk berpikir secara luas terhadap lapangan yang ada serta korelasi antara objek-objek yang menjadi kajian dalam filsafat yang bersifat medalam dan tidak terbataskan oleh alam pikiran manusia melalui ide-ide besar manusia melalui konsep dan teori sebagai landasan manusia berpijak untuk mendalami sesuatu dan untuk mengetahui hakikat nilai dan kebenaran nilai tersebut.

Selain itu, penggunaan kata filsafat merupakan bentuk pemberontakan yang dilakukan oleh Socrates sebagai protes terhadap kaum Sophist kaum terpelajar waktu itu yang menyatakan bahwa dirinya adalah orang-orang yang bijaksana, padahal kebijaksanaan mereka hanyalah semu belaka. Sebagai bentuk protes terhadap mereka, maka Socrates mengatakan bahwa lebih suka menyebut dirinya sebagai pencinta kebijaksanaan. Sebab itu, memberikan makna bahwa dalam filsafat setiap orang akan merasa bahwa dirinya tidak akan merasa sempurna dan akan selalu belajar. Secara umum dapat dikatakan bahwa filsafat merupakan pemikiran yang sedalam-dalamnya tentang semua hal yang berkaitan dengan manusia dan hidupnya. Jadi, filsafat akan berurusan dengan benda-benda,

\section{h. 2 .}

${ }^{1}$ Burhanuddin Salam, Sejarah Filsafat Ilmu dan Teknologi (Bandung: Rineka Cipta, 1993),

${ }^{2}$ P. Leenhouwers, Manusia dalam Lingkungannya: Refleksi Filsafat tentang Manusia, terj. K.J. Veege (Jakarta: Gramedia, 1970), h. 227-232.

${ }^{3}$ Salam, Sejarah Filsafat Ilmu dan Teknologi, h. 3. 
situasi-situasi, pertanyaan dan masalah yang sebelumnya telah dijumpai oleh orang baik di tingkat pengetahuan pra-ilmiah, maupun di tingkat pengetahuan ilmiah. ${ }^{4}$

Sementara menurut Harold Titus, merinci secara spesifik pengertian filsafat. Pertama, filsafat adalah sekumpulan sikap dan kepercayaan terhadap kehidupan dan alam yang bisa diterima secara kritis. Kedua, filsafat adalah suatu proses kritis atau pemikiran terhadap kepercayaan dan sikap yang sangat kita junjung tinggi. Ketiga, filsafat adalah usaha untuk mendapat gambaran secara keseluruhan. Keempat, filsafat merupakan analisis logika dari bahasan serta penjelasan tentang arti kata dan konsep. Kelima, filsafat adalah sekumpulan problem-problem yang langsung mendapat perhatian dari manusia dan yang dicari jawabannya oleh ahli filsafat. ${ }^{5}$

Pengertian filsafat yang memberikan makna secara mendalam, dimana dalam filsafat merupakan proses yang dilaksanakan dengan mendalam. Proses tersebut dapat terlihat melalui ciri pemikiran filsafat yang secara umum yaitu deskriptif, kritis dan analitis, evaluatif dan normatif, spekulatif, sistematis, mendalam, mendasar, serta menyeluruh. ${ }^{6}$

Dengan hal tersebut tentu akan memberikan gambaran akan lapangan filsafat yang masuk ke dalam semua kajian keilmuan. Karena itu, eksistensi filsafat ilmu sangat penting untuk mencapai kebenaran dan hakikat ilmu pengetahuan. Dalam filsafat ilmu, maka ada tiga lapangan akal pikiran dalam filsafat ilmu yaitu ontologi, epistimologi dan aksiologi.

Pertama, ontologi berasal dari bahasa yunani yaitu on (ada), dan ontos berarti keberadaan. Sedangkan logos berarti pemikiran. Jadi, ontologi adalah pemikiran mengenai yang ada dan keberadaannya. Dengan demikian ontologi membatasi diri pada kajian keilmuan yang dipikirkan secara rasional yang bisa diamati melalui pancaindra manusia. Wilayah ontologi terdapat pada jangkauan manusia. Manakala ruang kajian ontologi tidak hanya terbatas kepada pancaindra, melainkan juga pikiran (rasio), maka objek telaah menjadi tidak terbatas pada yang bersifat fisik tetapi metafisik.

Kedua, epistimologi sebagai sumber, struktur metode dan sahnya pengetahuan, maka keberadaannya menyangkut sangat erat dengan persoalan apa yang dapat diketahui dan bagaimana cara mengetahuinya, "what can we know and how do we know it", maka untuk prese metodis dalam rangka memperoleh kebenaran secara epistimologis harus ditopang dengan sistem.

Ketiga, aksiologi merupakan teori nilai yang berkaitan langsung dengan kegunaan dari ilmu pengetahuan. ${ }^{7}$ Ini menunjukan bahwa ilmu pengetahuan yang dimiliki dari sebuah hasil proses harus memiliki nilai yang memberikan kegunaan bagi manusia. Kekaguman

${ }^{4}$ Ibid., h. 20-21.

${ }^{5}$ Jalaluddin, Filsafat Ilmu Pengetahuan (Jakarta: RajaGrafindo Persada, 2003), h. 80.

${ }^{6}$ Ibid., h. 81.

${ }^{7}$ Ibid., h. 157-162. 
manusia pada pengetahuan, sebagai cermin budi yang terindah, kiranya semakin membuka mata pikiran (kesadaran) dan mata hati manusia, bahwa manusia sebagaimana pengetahuannya itu sendiri adalah terbatas. ${ }^{8}$ Keterbatasaan manusia terhadap ilmu pengetahuan harus terus melakukan pencarian. Karena itu, ketiga pijakan tersebut dalam filsafat ilmu menjadi bagian yang penting untuk mencapai kebenaran.

Dalam filsafat agama, sebagai bagian dari kajian filsafat, maka agama sebagai objek kajian filsafat memiliki dimensi sebagai lapangan kajian filsafat. Ini menunjukan bahwa agama tidak terlepas dari suatu yang ada sebagai ontologisnya dan perlu dikaji secara metodologis serta aksiologis sebagai kegunaan agama bagi manusia sejatinya yang memiliki pengetahuan dan rasio yang sejatinya tidakhanya pada aspek yang bersifat fisik matrial tetapi juga pada hal yang bersifat metafisik.

Selain itu, eksistensi filsafat sebagai master-scientiarum atau sebagai induk ilmu pengetahuan yang mempunyai peran besar bagi pengungkapan kebenaran pengetahuan melalui teori dan metode yang digunakan bagi manusia untuk melihat realitas kosmologi (alam) sebagai sebuah fenomena. ${ }^{9}$ Menurut R.F. Beerling, bahwa filsafat bersumber pada manusia dan mengenai manusia. Dia adalah tingkat tertinggi dari kegelisahan. Filsafat mengajukan pertanyaan yang dilakukan secara radikal sekali. Jawabannya yang akan memberikan kepuasaan pada pertanyaan-pertanyaan itu, tetapi selalu mengandung pertanyaanpertanyaan baru, sehingga tidak pernah tentram benar. ${ }^{10}$

Pertanyaan-pertanyaan tersebut dalam filsafat, maka akan memberikan pencerahan dan kebenaran terhadap apa yang ditanyakan melalui filsafat. Tidak hanya berhenti sampai di situ, melalui filsafat akan terus melahirkan pertanyaan-pertanyaan dan akan melahirkan kebenaran-kebenaran yang bersifat subjektif bahkan inter-subjektif yang harus terus dicari jawab atas pertanyaan tersebut.

\section{Konvergensi Agama dan Ilmu dalam Perspektif Filsafat}

Agama tentu tidak lepas dari berbagai perdebatan yang melahirkan paham-paham kepercayaan umat manusia terhadap nilai-nilai agama yang diyakini kebenarannya. Bahkan agama sering dijadikan alat untuk manusia menyatakan bahwa orang beragama sering memposisikan tuhan sebagai God of the gap. Ketika nalar tidak sampai untuk memahami misteri dan kompleksitas realitas semesta maka di situlah tuhan dihadirkan untuk

${ }^{8}$ Aholiab Watloly, Sosio-Epistemologi: Membangun Pengetahuan Berwatak Sosial (Yogyakarta: Kanisius, 2013), h. 20.

${ }^{9}$ Burhanuddin Salam, Pengantar Filsafat (Bandung: Bina Aksara, 1983), h. 100.

${ }^{10} \mathrm{Ibid}$, h, 115. Fenomenologi sebagai cabang filsafat telah diperbincangkan dalam tradisi filsafat kontinental di Eropa pada sebagaian besar abad-20. Secara garis besar bahwa "gerakan" percabangan fenemenologi dari filsafat. Lihat Alex Sobur, Filsafat Komunikasi Tradisi dan Metode Fenomenologi (Bandung: Rosada, 2013), h. Vi. 
menentramkan kebingungan. ${ }^{11}$ Ini menunjukan bahwa manusia sebagai seorang yang memiliki tingkat keterbatasan maka memerlukan sandaran " $X$ " untuk dipercayai eksistensinya.

Fakta yang menjadi bagian yang tidak terpisahkan ketika manusia mengatakan bahwa tidak ada korelasi antara agama dan ilmu, maka ini menjadi hampa. Seperti dalam teori relativitas Enstein yang kemudian mendapat dukungan dari revolusioner dari teori fisika kuantum, yang membicarakan tentang dunia mikro sub-atom, yang merombak total pandangan tentang materi. Dengan teori ini pandangan lama tentang atom-atom dunia mikroskopik adalah materi yang terkecil dari materi harus ditinggalkan karena tidak relevan. Artinya pada tingkat materi yang terkecil alam mengelak tidak bisa diketahui oleh mata manusia. Di sinilah kemudian para ilmuwan meyakini adanya ruang mistik dalam ilmu fisika yang selama ini diyakini sebagi ilmu pasti. ${ }^{12}$ Ruang-ruang tersebut tidak dapat dijangkau oleh manusia karena itu berada pada ruang-ruang metafisik. Ruang-ruang metafisik yang sulit ditembus oleh ilmu menjadikan manusia harus mengakui akan eksistensi X, yang merupakan pemilik alam semesta.

Menurut Aristoteles, bahwa metafisik berpusat pada persoalan barang dan bentuk. Bentuk dikemukakan sebagai pengganti pengertian, dan bentuk memberikan kenyataan kepada benda, sedangkan barang materi yang tidak mempunyai bangunan, substansi belaka yang menjadi pokok dari segala-galanya. ${ }^{13}$ Bentuk dan barang memberikan gambaran yang berbeda, ini menunjukkan adanya metafisik seperti ketika berbicara tentang atom, maka keberadaan atom yang sangat kecil, masih ada sesuatu yang lebih kecil. Padanganpandangan ini menunjukan akan apa yang disampaikan oleh John Polkinghorne, bahwa pandangan berikut ini adalah salah, "ketika seseorang memasuki laboratorium ia melupakan tuhannya dan ketika sesorang masuk ke dalam ajaran agamanya maka ia melukan sainsnya." ${ }^{14}$ Pandangan tersebut di atas seolah adanya pemisahan antara pengetahuan dan agama, ini menunjukan bahwa tidak adanya eksistensi " $X$ " yang menjadi tolak ukur nilai-nilai kebenaran yang menyatukan antara hakikat ilmu pengetahuan dengan hakikat yang bersifat metafisik, dimana dapat diketahui oleh manusia dengan indrawi dan rasio.

Karena itu, keberhasilan manusia dalam memperoleh ilmu-ilmu pengetahuan saat ini dapat dikaji ulang antara lain: ${ }^{15}$

${ }^{11}$ Komaruddin Hidayat dan Muhammad Wahyuni Nafis, Agama Masa Depan Perspektif Filsafat Perennial (Jakarta: Paramadina, 1995), h. 116.

${ }^{12}$ Ibid., h. 108.

${ }^{13}$ Mohammad Hatta, Alam Pikiran Yunani (Jakarta: Tintamas Indonesia, 1980), h. 127. ${ }^{14}$ Hidayat dan Nafis, Agama Masa Depan, h. 108.

${ }^{15}$ Nasrah, "Pengetahuan Manusia dan Epistimologi Islam," dalam http://repository.usu.ac.id. Diakses 15 Juli 2015. 


\begin{tabular}{|c|c|c|c|}
\hline $\begin{array}{l}\text { Cara memper- } \\
\text { oleh ilmu } \\
\text { pengetahuan }\end{array}$ & $\begin{array}{c}\text { Pengertian dan } \\
\text { perbedaan }\end{array}$ & $\begin{array}{l}\text { Metode ilmiah dan } \\
\text { struktur } \\
\text { pengetahuan ilmiah }\end{array}$ & $\begin{array}{l}\text { Treand dalam } \\
\text { pengkajian } \\
\text { ilmiah }\end{array}$ \\
\hline $\begin{array}{l}\text { 1. Trial and error } \\
\text { 2. Common sense } \\
\text { 3. Akal } \\
\text { 4. Pengalaman }\end{array}$ & $\begin{array}{l}\text { 1. Pengetahuan } \\
\text { 2. Ilmu } \\
\text { 3. Filsafat }\end{array}$ & $\begin{array}{l}\text { 1. Metode ilmiah } \\
\text { 2. Struktur pengetahun } \\
\text { ilmiah }\end{array}$ & $\begin{array}{l}\text { 1. Spesialisasi } \\
\text { 2. Interdesipliner } \\
\text { 3. Multidisipliner } \\
\text { 4. Kajian wilayah }\end{array}$ \\
\hline
\end{tabular}

Sebagai manusia yang memiliki indrawi dan rasio, maka manusia dituntut untuk mencari kebenaran. Imam al-Ghazâlî, adalah gambaran dari sosok yang haus akan ilmu dan kebenaran. Kendati demikian kebenaran yang dicapai akhirnya bersifat subjektif atau inter-subjektif. Al-Ghazâlî akan kesulitan menerangkan kriteria objektif dari kebenaran yang dia dapatkan. Padahal, suatu ilmu menuntut adanya kriteria yang jelas, motode yang konsisten, dan objektif. Dengan demikian, al-Ghazâlî baru memberikan semangat kebenaran, tetapi belum memberikan standar kebenaran. ${ }^{16}$ Kebenaran yang bersifat subjektif bahkan inter-subjektif tentu membuat manusia akan selalu mencari kebenaran itu sendiri dan manusia tidak tekungkung oleh paham yang bersifat ego, dimana meyakini atas segala kebenaran yang diyakininya adalah kebenaran semata.

Dalam perkembangan agama dan ilmu pengetahuan, maka pada titik tersebut terjadinya perdebatan dalam rangka untuk melihat kovergensi terhadap agama dan pengetahuan, oleh karena itu dapat dilihat dari berbagai dialog diantara keduanya, antara lain: ${ }^{17}$ Pertama, kubu konflik memandang agama dan sains secra intrinsik berlawanan. Keduanya bertarung untuk saling menyalahkan, bahkan saling meniadakan. Barbour diwakili oleh bibilical literalis dan kelompok scientific materialism berkeyakinan bahwa kitab suci berlaku universal, valid, final, dan memberikan data kebenaran yang tidak terbantahkan. Sedangkan, scientific materialism berpendirian bahwa metode ilmiah adalah satu-satunya cara yang tepat untuk mendapatkan pengetahuan. Golongan ini hanya percaya realitas yang nyata dan dapat dibuktikan secara material. Kedua, kubu kontras memandang agama dan sains masing-masing memiliki persoalan, wilayah kerja, metode sendiri-sendiri yang otonom, terpisah dan absah. Keduanya tidak perlu bertemu (contact). Ketiga, kubu kontak atau dialog menyarankan agar agama saling bertukar pandangan dengan sains untuk memperkaya perspektif tentang realitas. Kelima, kubu konfirmasi atau integrasi menyarankan agar agama dan sains agar saling mengukuhkan, terutama dalam pandangan anggapan dasar realitas tanpa harus kehilangkan identitas masing-masing. Model ini dianggap paling ideal.

Pandangan-pandangan tersebut di atas menjadi sebuah realitas yang terjadi dimasyarakat yang pada akhirnya melahirkan dikotomi terhadap agama dan sains itu sendiri, tetapi pada hakikatnya menurut Imam Thalhah dan Ahmad Barizi, bahwa adanya dikotomi tersebut

\footnotetext{
${ }^{16}$ Amsal Bakhtiar, Filsafat Agama 1 (Jakarta: Logos, 1997), h. 29.

${ }^{17}$ Hasan Baharun dan Akmal Mundiri, Metodologi Studi Islam: Percikan Pemikiran Tokoh dalam Membumikan Agama (Jogjakarta: Ar-Ruzz Media, 2011), h. 43-44.
} 
lebih kepada perbedaan terjadi pada sumber dan medan garapan berbeda, juga perbedaan pada titik tolak. ${ }^{18} \mathrm{Hal}$ inilah yang kemudian menjadi perdebatan, sehingga melahirkan berbagai pandangan dan asumsi-asumsi dasar atas kemungkinan terjadinya konvergensi antara keduanya.

\section{Keyakinan atas Kebenaran Sains bagi Manusia}

Kebenaran yang disampaikan oleh al-Ghazâlî menunujukan bahwa kebenaran bersifat subjektif. Perjalanan al-Ghazâlî dalam kehidupannya untuk mencari kebenaran tidak tercapai, bahkan al-Ghazâlî melihat kepada dirinya bahwa kebenaran yang diyakini benar kemudian menjadi kebenaran yang bersifat subjektif bahkan tidak hanya subjektif tetapi inter-subjektif, sehingga al-Ghazâlî melihat bahwa proses tersebut tidak dapat memberikan kriteria dari kebenaran. Pengalaman al-Ghazâlî tentu menjadi pengalaman yang berharga seorang filosof yang mencoba menemukan kebenaran itu sendiri.

Ketika manusia berbicara tentang kebenaran pengetahuan, maka ini menunjukkan akan adanya epistimologi yang membahas dari mana ilmu tersebut ada dan metode untuk menunjukan bahwa ilmu tersebut berasal. Ini menggambarkan bahwa keberadaan dari hakikat kebenaran ilmu diperlukan untuk memberikan bukti nyata akan suatu objek yang menjadi bagian yang tidak terpisahkan untuk menentukan hakikat kebenaran ilmu.

Secara umum ada dua teori yang digunakan untuk menentukan hakikat kebenaran, yaitu teori realisme dan teori idealisme. Dalam pandangan realisme, bahwa pengetahuan menurut realisme adalah gambaran atau kopi yang sebenarnya dalam alam nyata. Menurut Rasijdi, bahwa penganut agama perlu mempelajari teori realisme, dengan alasan berikut:

Pertama, dengan menjelaskan kesulitan-kesulitan dalam pikiran. Kesulitan pikiran tersebut adalah pendapat yang mengatakan bahwa tiap-tiap kejadian dapat diketahui hanya dari segi subjektif. Menurut Rasjidi, pernyataan ini tidak benar sebab adanya faktor subjektif bukan berarti menolak faktor objektif. Kalau seorang melihat sebatang pohon, tentu pohon itu dilihat sebagai pohon subjek. Namun, hal ini tidak berarti meniadakan pohon yang mempunyai wujud tersendiri. Begitu juga ketika orang berdoa kepada Tuhan, tetapi tuhan mempunyai wujud tersendiri.

Kedua, dengan jalan memberi pertimbangan-pertimbangan yang positif, menurut Rasjidi, umumnya orang beranggapan bahwa tiap-tiap benda mempunyai satu sebab. Contohnya, apa yang menyebabkan Ahmad sakit. Biasanya manusia puas ketika dijawab karena kuman. Sebenarnya, sebab sakit itu banyak sekali karena ada orang yang bersarang kuman dalam tubuhnya, tetapi dia tidak sakit. Dengan demikian, penyakit si ahmad itu mungkin disebabkan keadaan badannya, dan iklim. Prinsip semacam ini, menurut Rasjidi,

${ }^{18}$ Imam Tolkhah dan Ahmad Barizi, Membuka Jendela Pendidikan: Mengurai Akar Tradisi dan Integrasi Keilmuan Pendidikan Islam (Jakarta: RajaGrafindo Persada, 2004), h. 24. 
bisa digunakan mempelajari agama karena adanya keadaan yang subjektif tidak berarti tidak adanya keadaan yang objektif. ${ }^{19}$

Sedangkan teori kedua tentang teori idealisme. Ajaran idealisme berpandangan bahwa untuk mendapatkan pengetahuan yang benar-benar sesuai dengan kenyataan adalah mustahil. ${ }^{20}$ Dalam teori idealisme ini menggambarakan akan lahirnya subjektifitas dalam pengetahuan. Subjektifitas dalam pengetahuan tentu tidak mampu untuk menggambarkan hakikat dari apa yang disebut kebenaran pengetahuan. Dua sudut pandang yang menggambarkan akan kebenaran pengetahuan melalui teori realisme dan teori idealisme yang menjadi dasar lahirnya objektifitas dan subjektifitas ilmu.

Jalan untuk memperoleh pengetahuan merupakan bagian dari tidak dapat dipisahkan dari dua teori penemuan jalan pengetahuan, dimana keduanya memiliki pandangan yang berbeda-beda terhadap pengetahuan. Ini dapat dilihat dari pandangan teori empirisme dan rasionalisme. Teori empirisme menggambarkan bahwa pengetahuan didapatkan melalui pancaindra. Teori empirisme ini merupakan teori John Lock, dimana John Lock dengan tabula rasa-nya, menggambarakan manusia lahir dalam keadaan catatan kosong, catatan tersebut nanti akan di sisi ketika dia lahir di dunia maka ia akan mengisi melalui pancaindaranya. David Hume melanjutkan pemahaman ini dengan mengatakan bahwa manusia dilahirkan tanpa pengetahuan, dan manusia akan mendapatkan pengetahuan ketika manusia sudah menggunakan pancaindranya sebagai pengamatan.

Teori rasionalisme, dimana bahwa sumber dari ilmu adalah akal. Melalui pancaindra manusia melihat segala sesuatu, tetapi yang menghubungkan antara apa yang dilihat oleh manusia adalah akal. Ini menunjukan bahwa akal memiliki fungsi yang besar terhadap pengamatan pancaindra. Descrates merupakan tokoh rasionalisme, dalam pandangannya kebenaran tidak dapat diragukan lagi, tetapi dia tidak ragu bahwa dia ragu. Ini menggambarkan bahwa antara pancaindra dan akal memiliki hubungan dalam teori ini, dimana pancaindra sebagai pengamatan dan akal yang menghubungkan antara data yang ada.

Dua teori tersebut merupakan bagian dari proses untuk mencari kebenaran melalui jalan mencari. Kebenaran pengetahuan walaupun bersifat subjektif, tetapi melalui proses yang terjadi merupakan kewajiban kodrati bagi manusia untuk melakukan proses tersebut baik melalui teori empirisme yang bersandarkan kepada pancaindra atau melalui teori rasionalisme melalui jalan pancaindra dan akal budi sebagai penghubung terhadap datadata yang didapatkan oleh pancaindra dan dihubungkan oleh akal budi.

\section{Sains dalam Perspektif Islam dan Filsafat}

Sebagaimana telah diuraikan tentang keberadaan ilmu melalui teori realisme dan

\footnotetext{
${ }^{19}$ Bakhtiar, Filsafat Agama 1, h. 29.

${ }^{20} I b i d .$, h. 37-38.
} 
idealisme serta pandangan al-Ghazâlî terhadap kebenaran yang menurut dirinya dianggap benar, tetapi kemudian melahirkan subjektifitas bahkan inter-subjektifitas terhadap kebenaran itu sendiri. Selain itu, jalan menuju kebenaran pengetahuan pun telah penulis sampaikan dalam sub bab sebelumnya dengan menggunakan dua teori empirisme dan rasionalisme. Kedua pandangan itu tentu dapat menjadi ajaran dalam memahami pengetahuan yang bersumber melalui pancaindra dan akal sebagai basis dari lahirnya ilmu.

Hal tersebut tidak dapat dipungkiri bahwa pancaindra dan akal memiliki peran penting dalam melahirkan pengetahun, tetapi pengetahuan tidak dapat besifat mutlak kebenarannya, seperti yang diungkapkan di atas dan apa yang terjadi pada al-Ghazâlî yang merasa bahwa dirinya tidak dapat menemukan kebenaran yang objektif, tetapi kebenaran subjektif dan tidak dapat menentukan standar kebenaran.

Dalam kontek pemahaman terhadap agama, kebenaran tentu menjadi nilai yang objektif bukan lagi nilai yang bersifat subjektif. Menurut Frithjof Schuon, dalam bukunya berjudul the Transfiugration of Man, dinyatakan bahwa "it has been said that one must see God in everything; it has also been said that one must see everything" (seorang harus mampu melihat Tuhan dalam segala sesuatu, dan ia juga mesti melihat segala sesuatu dalam Tuhan). ${ }^{21}$ Pengertian secara terminologi menunjukan bahwa eksistensi tuhan itu ada, dan eksistensi tersebut akan menjadikan arah bagi manusia dalam melakukan pengamatan melalui pancaindra dan akal.

Islam merupakan agama yang bersumber dari pemahaman untuk memberikan keselamatan kepada manusia. Hal tersebut dapat dilihat dalam konteks arti Islam dari sisi bahasa, di mana Islam berasal dari kata aslama-yuslimu-islâman, artinya membawa keselamatan bagi umat manusia. Nilai-nilai kebenaran dalam Islam dibangun atas dasar kepercayaan terhadap sesuatu yang bersifat Esa, kosmologi yang diciptakan oleh Allah sebagai wujud dari adanya keesaan Allah yang menciptakan alam semesta termasuk manusia.

Dalam toeri empirisme John Lock (Tabula Rasa), manusia digambarkan seperti catatan kosong ketika lahir, dan catatan tersebut kemudian akan diisi ketika manusia itu lahir. Teori empirisme John Lock ini menganggap manusia lahir tanpa ada proses, sehingga dianggap tidak ada catatan sama sekali. Dalam perspektif Filsafat Islam, bahwa proses penciptaan manusia itu merupakan awal adanya proses terjadinya perjanjian-perjanjian manusia dengan tuhannya. Ini dapat terlihat dari ayat-ayat al-Qur'an berikut, "bacalah dengan (menyebut) nama Tuhanmu Yang menciptakan, Dia telah menciptakan manusia dari segumpal darah" (Q.S. al-Alaq/96: 1-2); "kemudian Kami jadikan saripati itu air mani (yang disimpan) dalam tempat yang kokoh (rahim); Kemudian air mani itu Kami jadikan segumpal darah, lalu segumpal darah itu Kami jadikan segumpal daging, dan segumpal daging itu Kami jadikan tulang belulang, lalu tulang belulang itu Kami bungkus dengan daging.

${ }^{21}$ Zaprukhan, Filsafat Umum: Sebuah Pendekatan Tematik (Jakarta: RajaGrafindo Persada, 2002), h. 352. 
Kemudian Kami jadikan dia makhlukyang (berbentuk) lain. Maka Maha sucilah Allah, Pencipta Yang Paling Baik. (Q.S. al-Mu'minûn/23: 13-14)"; "Dan yang memulai penciptaan manusia dari tanah, kemudian Dia menjadikan keturunannya dari saripati air yang hina (air mani)." (Q.S. al-Sajadah/32: 7-8); "Dia menjadikan kamu dalam perut ibumu kejadian demi kejadian dalam tiga kegelapan" (Q.S. al-Zumar/39: 6)"; dan "Dan Dia lebih mengetahui (tentang keadaan)mu ketika Dia menjadikan kamu dari tanah dan ketika kamu masih janin dalam perut ibumu" (Q.S. al-Najm/53: 32)".

Proses penciptaan manusia yang mengalami masa periodesasi dalam perut ibunya, tentu menunjukan bahwa ada perjanjian yang dibuat oleh manusia dengan sang penciptanya yaitu Allah SWT. Ini menunjukan bahwa manusia ketika lahir dianggap sebagai catatan kosong merupakan bagian yang tidak mengakui adanya proses penciptaan manusia dan hubungannya manusia terhadap Tuhannya atau Allah SWT dalam Islam, "sesungguhnya Aku akan menciptakan manusia dari tanah, maka apabila telah Ku sempurnakan kejadiannya dan Kutiupkan kepadanya ruh (ciptaan)-Ku, maka hendaklah kamu tersungkur dengan bersujud kepadanya" (Q.S. Shâd/38: 71-72).

Dalam Islam, al-Qur'an menyatakan bahwa Allah SWT. menciptakan manusia dari sebuah proses panjang, dan pada akhirnya menjadi wujud yang memiliki pancaindra. Pancaindra berfungsi untuk melakukan sesuatu seperti memegang, dan melihat. Manusia sebagai insan yang diberikan hal-hal tersebut, tentu manusia diberikan rasio atau akal oleh Allah SWT., maka manusia disebut dengan istilah hayawan al-nâtiq. Ini menunjukan bahwa manusia memiliki kesempurnaan dalam penciptaannya.

Jika dipandang dari sudut teori rasionalisme, maka akan terlihat bahwa Alllah SWT menciptakan manusia penuh dengan kesempurnaan fí ahsani taqwîm (sebaik-baiknya penciptaan). Proses penciptaan manusia dan diberikannya pancaindra serta akal merupakan bagian dari proses anak adam untuk melihat dan memikirkan ciptaan-ciptaan Allah SWT.

Pancaindra dan akal merupakan bagian yang saling berkorelasi antara keduanya, sehingga dengan hal tersebut akan melahirkan pengetahuan. Dari pengetahuan yang melalui proses yang panjang, tentu akan melahirkan ilmu pengetahuan yang secara sistematis dilalui melalui proses metodologis. Ini dapat dipahami dalam Q.S. al-Rahmân/55: 33, dimana Allah SWT. menyatakan bahwa manusia sebagai ahsan taqwîm adadua hal yang menjadi kekuatan besar untuk menciptakan pengetahuan menjadi ilmu pengetahuan yaitu dengan pancaindra dan akal. Allah SWT. berfirman, "wahai jin dan manusia, jikalau kamu dapat menembus langit dan bumi, maka tembuslah, sekali-kali kamu tidak akan mampu menembusnya kecuali dengan kekuatan (Q.S. al-Rahmân: 33). Kekuatan tersebut adalah ilmu, dalam teori realisme dapat dilihat menyatunya pancaindra dan akal sehingga melahirkan ilmu. Menurut David Trublood, bahwa tumbuhnya pengetahuan itu lambat dan penuh dengan daya upaya. Dimulai dengan pengalaman yang tidak dimulai dengan pikiran-pikiran untuk menyesuaikan diri dengan alam, akhirnya sampai kepada suatu 
tingkat dimana membedakan antara subjek dan obyek dan mengetahui sistem alam sendiri dan terpisah dari kemampuan-kemampuan manusia. ${ }^{22}$

\section{Islam sebagai Pencerahan terhadap Sains bagi Manusia}

Membaca, dalam artinya yang luas, merupakan aktivitas utama dalam kegiatan ilmiah. Di samping itu, kata ilmu yang telah menjadi bahasa Indonesia bukan sekedar berasal dari bahasa Arab, tetapi juga tercantum dalam al-Qur'an. Kata ilmu disebut sebanyak 105 kali dalam al-Qur'an. Sedangkan kata jadiannya disebut sebanyak 744 kali. Kata jadian yang dimaksud adalah 'alima (35 kali), ya lamu (215 kali), i lâm (31 kali), yu lamu (1 kali), 'alîm (18 kali), ma lûm (13 kali), 'âlamîn (73 kali), 'alam (3 kali), alam (49 kali), 'alîm atau 'ulamâ' (163 kali), 'allâm (4 kali), 'allama (12 kali), yu'limu (16 kali), 'ulima (3 kali), mu'allâm (1 kali), dan ta'allama (2 kali). ${ }^{23} \mathrm{Hal}$ tersebut bahwa Islam sebagai agama tidak hanya melihat dari sudat pandang sipiritual semata, tetapi ilmu menjadi bagian dari al-Qur'an sebagai perintah kepada umat manusia untuk menggalinya. bahkan wahyu yang pertama kali turun adalah ayat yang berkenaan dengan ilmu yakni perintah untuk membaca seperti yang terdapat dalam Q.S. al-Alaq/96: 1-5, "bacalah dengan (menyebut) Nama Tuhanmu yang menciptakan. Dia telah menciptakan manusia dari segumpal darah. Bacalah dan Tuhanmulah Yang Paling Pemurah. Yang mengajar (manusia) dengan perantaraan kalam. Dia mengajarkan kepada manusia apa yang tidak diketahuinya."

Sardar mengatakan bahwa ciri yang unik dari sains (ilmu) Islam adalah penekanannya pada kesatuan agama dengan sains, pengetahuan dan nilai, fisika dan metafisika. Pada prinsipnya, ilmu merupakan salah satu dari keseluruhan konsep-konsep Islam yang sangat fundamental, sebagai suatu agen formatif yang membentuk pandangan peradaban Islam. ${ }^{24}$ Konsep ilm (ilmu) menyatukan hampir seluruh bentuk pengetahuan, dari pengamatan murni sampai metafisika yang paling tinggi. ' $\mathrm{Ilm}$ merupakan sistem pengetahuan yang di dalamnya terkandung berbagai bentuk pengetahuan, baik pengetahuan-pengetahuan metafisik, empiris, maupun eksakta. Bentuk-bentuk pengetahuan tersebut tidak dapat dipisahkan satu sama lain, tetapi harus dipahami di dalam sebuah kerangka kesatuan. "Semua bentuk pengetahuan tersebut saling terkait dan secara organis dihubungkan oleh jiwa wahyu al-Qur'an yang selalu hidup," 25 "Katakanlah: sekiranya lautan menjadi tinta

\footnotetext{
${ }^{22}$ David Trublood, Philosopy of Relegion (Filsafat Agama), terj. M. Rasjidi (Jakarta: Bulan Bintang, 1965), h. 52.

${ }^{23}$ Mohammad Kosim, "Ilmu Pengetahuan dalam Islam (Perspektif Filosofis-Historis)," dalam http://ejournal.stainpamekasan.ac.id. Diakses 12 Juni 2015.

${ }^{24}$ Ziauddin Sardar, Masa Depan Islam, terj. Rahmani Astuti (Bandung: Pustaka, 1987), h. 180; Fuady Ramly, "Kontribusi Pemikiran Islam Kontemporer bagi Pengembangan Filsafat IlmuIlmu Keislaman," dalam Ar-Raniry: International Journal of Islamic Studies, Vol. 1, No. 2, Desember 2014, h. 226.

${ }^{25}$ Ibid.
} 
untuk (menulis) kalimat-kalimat Tuhanku, sungguh habislah lautan itu sebelum habis (ditulis) kalimat-kalimat Tuhanku, meskipun Kami datangkan tambahan sebanyak itu (pula)" (Q.S. al- Kahfi/18:109.

Lapangan yang menjadi kajian dari Ilmu-ilmu Allah tidak akan terbatas dan merupakan bagian yang harus dilakukan proses mencari kebenaran terhadap setiap apa yang di ciptakan oleh Allah melalui wahyu yang diturunkan oleh Allah kepada umat manusia. Allah SWT. melalui ayat-ayat wahyunya yang diturnkan meminta manusia untuk selalu berpikir terhadap apa yang diciptakan oleh Allah SWT. Apabila dicoba untuk menghubungan terhadap berbagai teori terhadap kebenaran ilmu, tentu melalui wahyu dalam bentuk ayat-ayatnya menjadi gambaran akan keimanan manusia kepada Allah SWT. Dalam al-Qur'an, "Dia menciptakan langit tanpa tiang yang kamu melihatnya dan Dia meletakkan gunung-gunung (di permukaan) bumi supaya bumi itu tidak menggoyangkan kamu; dan memperkembang biakkan padanya segala macam jenis binatang." (Q.S. Luqmân/ $31: 10)$.

Ilmu dalam Islam yang melalui proses ilmillah dan ilmiah menjadi satu ke satuan dan tidak dapat terpisahkan. Pancaindra dan akal manusia sebagai basis dari upaya untuk menghasilan ilmu pengetahuan tentu tidak hanya berakar terhadap ilmu pengetahuan saja, tetapi pada sisi yang paling dalam dari upaya tersebut adalah menemukan kebenaran objektif terhadap keimanan sebagai manusia.

Dalam asmâ' al-husna sebagai sifat-sifat Allah Yang Agung, disebutkan bahwa Allah adalah al-Alîm, dengan kedudukan Allah sebagai Yang Maha Tahu, maka ada kedudukan manusia sebagai hambanya yaitu al-muta'allim, dalam kontek kedudukan manusia sebagai al-muta'alim, maka manusia sebagai ciptaanya dan dengan pancaindra serta akal yang diberikan oleh Allah SWT. menjadikan manusia harus terus melakukan eksplorasi apa yang dilihat dan dipikirkan oleh akal. Hal tersebut akan mendorong lahirnya pengetahuan yang pada akhirnya akan menjadikan Ilmu dengan berlandaskan nilai-nilai keimanan kepada Allah SWT. Hal tersebut dapat diartikan sebagai bagian dari realitas empiris yang didukung oleh realitas transendental yaitu Iman.

\section{Penutup}

Diskursus terhadap kebenaran ilmu, maka ini menunjukkan akan adanya epistimologi yang membahas dari mana ilmu tersebut ada dan metode untuk menunjukan bahwa ilmu tersebut berasal. Ini menggambarkan bahwa keberadaan dari hakikat kebenaran ilmu diperlukan untuk memberikan bukti nyata akan suatu objek yang menjadi bagian yang tidak terpisahkan untuk menentukan hakikat kebenaran ilmu. Secara umum ada dua teori yang digunakan untuk menentukan hakikat kebenaran, yaitu teori realisme dan teori idealisme. Dalam pandangan realisme, bahwa ilmu menurut realisme adalah gambaran yang sebenarnya dalam alam nyata. Sedangkan teori kedua tentang teori idealisme. Ajaran idealisme ber- 
pandangan bahwa untuk mendapatkan ilmu yang benar-benar sesuai dengan kenyataan adalah mustahil. Selain itu, jalan untuk memperoleh pengetahuan merupakan bagian dari tidak dapat dipisahkan dari dua teori penemuan jalan ilmu, dimana keduanya memiliki pandangan yang berbeda-beda terhadap ilmu. Ini dapat dilihat dari pandangan teori empirisme dan rasionalisme. Teori-teori tersebut sebagai bagian dari upaya untuk mendapatkan kebenaran dan jalan untuk mendapatkan pengetahuan yang berproses menjadi Ilmu. Dalam perkembangan agama dan ilmu pengetahuan, maka pada titik tersebut terjadinya perdebatan dalam rangka untuk melihat konvergensi terhadap agama dan pengetahuan. Karena itu dapat dilihat dari berbagai dialog di antara keduanya. Pertama, kubu konflik memandang agama dan sains secara intrinsik berlawanan. Keduanya bertarung untuk saling menyalahkan, bahkan saling meniadakan. Barbour diwakili oleh bibilical literalis dan kelompok scientific materialism berkeyakinan bahwa kitab suci berlaku universal, valid, final, dan memberikan data kebenaran yang tidak terbantahkan. Sedangkan, scientific materialism berpendirian bahwa metode ilmiah adalah satu-satunya cara yang tepat untuk mendapatkan pengetahuan. Golongan ini hanya percaya realitas yang nyata dan dapat dibuktikan secara material. Kedua, kubu kontras memandang agama dan sains masingmasing memiliki persoalan, wilayah kerja, metode sendiri-sendiri yang otonom, terpisah dan absah. Keduanya tidak perlu bertemu (contact). Ketiga, kubu kontak atau dialog menyarankan agar agama saling bertukar pandangan dengan sains untuk memperkaya perspektif tentang realitas. Keempat, adapun kubu konfirmasi atau integrasi menyarankan agar agama dan sains agar saling mengukuhkan, terutama dalam pandangan anggapan dasar realitas tanpa harus kehilangan identitas masing-masing. Model ini dianggap paling ideal.

Dalam perspektif Islam, pancaindra dan akal/rasio manusia sebagai basis dari upaya untuk menghasilkan ilmu tentu tidak hanya berakar terhadap ilmu semata sebagai kebenaran mutlak, tetapi pada sisi yang paling dalam dari upaya tersebut adalah menemukan kebenaran objektif terhadap keimanan sebagai manusia. Hal tersebut dapat diartikan sebagai bagian dari realitas empiris yang didukung oleh realitas transendental yaitu iman, seperti dalam Q.S. al-Kahfi/18: 109. Nilai-nilai transendental menjadi nilai utama untuk mencapai kebenaran ilmu.

\section{Pustaka Acuan}

Alex Sobur. Filsafat Komunikasi: Tradisi dan Metode Fenomenologi. Bandung: Rosada, 2013.

Baharun, Hasan dan Akmal Mundiri. Metodologi Studi Islam: Percikan Pemikiran Tokoh dalam Membumikan Agama. Jogjakarta: Ar-Ruzz Media, 2011.

Bakhtiar, Amsal. Filsafat Agama 1. Jakarta: Logos, 1997.

Hatta, Mohammad. Alam Pikiran Yunani. Jakarta: Tintamas Indonesia, 1980. 
MIQOT Vol. XXXIX No. 2 Juli-Desember 2015

Hidayat, Komaruddin dan Muhammad Wahyuni Nafis. Agama Masa Depan Perspektif Filsafat Perennial. Jakarta: Paramadina, 1995.

Jalaluddin. Filsafat Ilmu Pengetahuan. Jakarta: RajaGrafindo Persada, 2013.

Leenhouwers, P. Manusia dalam Lingkungannya: Refleksi Filsafat tentang Manusia, terj. K.J. Veege. Jakarta: Gramedia, 1970.

Mohammad Kosim. "Ilmu Pengetahuan dalam Islam: Perspektif Filosofis-Historis," dalam http://ejournal.stainpamekasan.ac.id., diakses 12 Juni 2015.

Nasrah. "Pengetahuan Manusia dan Epistimologi Islam," dalam http://repository.usu.ac.id. Diakses 15 Juli 2015.

Ramly, Fuady. "Kontribusi Pemikiran Islam Kontemporer Bagi Pengembangan Filsafat IlmuIlmu Keislaman," dalam Ar -Raniry: International Journal of Islamic Studies, Vol. 1, No. 2, Desember 2014.

Salam, Burhanuddin. Pengantar Filsafat. Bandung: Bina Aksara, 1983.

Salam, Burhanuddin. Sejarah Filsafat Ilmu dan Teknologi. Bandung: Rineka Cipta, 1993.

Tolkhah, Imam, dan Ahmad Barizi. Membuka Jendela Pendidikan: Mengurai Akar Tradisi dan Integrasi Keilmuan Pendidikan Islam. Jakarta: RajaGrafindo Persada, 2004.

Trublood, David. Filsafat Agama, terj. M. Rasjidi. Jakarta: Bulan Bintang, 1965.

Watloly, Aholiab. Sosio-Epistemologi: Membangun Pengetahuan Berwatak Sosial. Yogyakarta: Kanisius, 2013.

Zaprukhan. Filsafat Umum: Sebuah Pendekatan Tematik. Jakarta: RajaGrafindo Persada, 2002. 